\title{
Missionary Method of Mother Teresa of Calcutta
}

\author{
Annamma.M.A. \\ Research Scholar, Department of Christian Studies, University of Mysore, Manasagangotri,Mysore, Karnataka \\ State, India.
}

\begin{abstract}
Mother Teresa of Calcutta the Prophetic activist, a model for mission today, based on the Gospel values of Jesus Christ.

Key words: Mother Teresa, India,Mission, Missionary, Christians, Buddha, Buddhism, Church, inculturation, inter-religious.

The $103^{\text {nd }}$ Birth Anniversary of Mother Teresa was an incentive to reflect on her missionary method. Ongoing reflection will keep her memory alive and we can draw inspiration from this noble soul. In the context of the mission in India and contemporary experience, the method spearheaded by Mother Teresa and her extraordinary success seem to hold great promises for the future of the mission in India. Her understanding of mission and the strategies she employed seem to be eternally valid.
\end{abstract}

\section{A Historical Overview of Missionary Work in India}

The Church has been missionary from the beginning. The apostles took the command of the risen Jesus seriously. The New Testament in general and the Acts in particular bear witness to this fact. Impelled by the overwhelming experience of the Spirit poured out on Pentecost, we find an all out missionary movement undertaken by the apostles in particular and even by ordinary believers. After the murder of Stephen the believers were scattered and wherever they went they proclaimed Jesus. It consisted in preaching often accompanied by miracles (works of power). This is the reason for the rapid spread of Christianity to the ends of the earth. Most of Asia Minor and the whole of Europe was converted to Christianity. The origin of the church in India is also the result of the missionary movement launched by the apostles. St. Thomas, one of the apostles of Jesus is believed to have brought the Christian faith to the shores of India in the year 52 A.D.

However the missionary movement in India is generally associated with the arrival of the colonizers. It is generally accepted that the pre-colonial church of St. Thomas Christians did not do much in the field of mission work. ${ }^{1}$ The colonial period on the other hand, witnessed organized efforts aimed at the change of India to Christianity. Their evangelical enterprise had the blessings of the pope and colonial patronage. This period produced zealous missionaries like St. Francis Xavier. All the resources of the Church - both personal and material - were mobilised to this end. In some places like Goa there were even cases of forced conversion and persecution of Non-Christians.

The missionary dynamism of the Church continued unabated even after independence. In the course of time all the necessary infra-structure for the training of local missionaries and continued mission work were set up. But with all that today Christians constitute only a small minority of $2.5 \%$ of the total Indian population. Statistics show that the number of Christians in recent times has not shown any substantial increase, instead, their number is coming down. ${ }^{2}$ It shows that Christianity did not make much headway not only in so far as the numbers are concerned, but also in terms of its impact on the social life of India. It failed to produce results proportionate to the efforts and investment, both men and material.

\section{Reasons for the Failure of the Traditional Mission in India}

Analysts attribute the failure of Christian mission in India to the lack of inculturation and the failure of the church to produce real men and women of sanctity. They maintain that genuine inculturation and rootedness in the contemplative tradition of India will certainly produce positive results and Christian mission will thrive. Without underestimating the importance of inculturation and holiness of life, I would like to point out that the future of mission in India - mission understood in terms of conversion of Indians to Christianity - is bleak. This is not to compromise Christian hope, but is an affirmation of Christian realism. This thesis can be verified from the experience of the past and present.

\footnotetext{
${ }^{1}$ Paul Thenayan, The Missionary Consciousness of the Thomas Christians (Cochin: Vani Publications, 1982), 34.

${ }^{2}$ T. K. John, "Image of the Christian Presented in India Today," Kurien Kunnumpuram, Errol D'Lima and Jacob Parappally, eds., The Church in Search of a New Identity: The $19^{\text {th }}$ Annual Meeting of the Indian Theological Association 4-8, May 1996 (Bangalore: NBCLC, 1997), 126-127.
} 


\subsection{Failure to inculturate}

It is true, the Churches established by the missionaries developed an un-Indian identity. They were foreign in every way. The European face of Christianity was disliked by many good willed Indians, especially those of the high caste. In fact there were repeated pleas to abandon the western garb and tailor an Indian dress for the Christian faith in India. The Oriental Christ of Pratap Chandra Mozoomdar is to be seen against this background. But would such an adaptation along the lines suggested by the champions of inculturation have resulted in the conversion of India to Christianity? The answer is a firm no. Let us take the history of Buddhism. No one can argue that Buddhism was not inculturated. It was not a foreign religion, nor was it introduced into India by foreign missionaries. Gautama Buddha was a son of the soil and was deeply rooted in the traditions and culture of the country. History does not record that his followers later on abandoned the Indian ways and put on foreign life- style. No one can also doubt the holiness and sanctity of Buddha or even of his followers. Buddhist non-violence and compassion for all forms of life has become mythical.

Like Christianity, Buddhism too was a missionary religion. After his enlightenment Buddha went about preaching the new way of Nirvana - liberation. He also sent out missionaries all over the country to preach the new faith. But we know from history that the success was limited. Later on many of the converts reverted back to Hinduism. In spite of almost two thousand five hundred years of Buddhist presence, witness and mission in India, it has not spread in the country in any significant way. According to statistics today Buddhists constitute a mere $0.75 \%$ of the total Indian population. And one should not forget that this total includes also those 200,000 and odd dalits of the Mahar community under Ambedkar who embraced Buddhism in 1956 in protest against the discriminatory caste system of Hinduism. Outside India, on the other hand, it spread fast so that today we have vibrant Buddhist communities all over Asia. In several Asian countries they constitute the majority. Why did Buddhism fail in India in spite of it being fully rooted in the culture and traditions of the country and in spite of it producing generations of men and women outstanding in holiness?

\subsection{Sporadic efforts at inculturation}

It is true that Christianity was not inculturated. It remained by and large alien. But the history of colonial Christianity also witnessed sporadic efforts at inculturation. The Italian Jesuit missionary, Robert De Nobili's inculturational efforts are a case in point. It is true he won some high caste Hindus for Christianity. But much of the limited success he had may be attributed to the personal charisma and persuasive power of De Nobili rather than to genuine conversion, resulting from a deep experience of God. If the latter were the case, how can we explain the abandonment of faith by many of his converts, and that too at a time when there was no persecution? But the fact that many of his converts reverted back to Hinduism already during his life time, and many others, after his death, shows that these were not genuine conversions. The revival of the method by Brahmabhandab Upadhyaya and others also did not produce significant results.

Since more than half a century we see the growth of Christian Ashram movement ${ }^{3}$ in India. It is certainly a form of genuine inculturation into the religious traditions of the country. Everything in the Ashram, and the whole ashramic atmosphere, give a sense of the Indian. How many conversions have been effected by the Ashram movement?

In the same way inter-religious dialogue, another important aspect of inculturation has been one of the priorities of the Indian church. Dialogue of life has been going on in India from time immemorial. After Vatican II organized forms of dialogue have gathered momentum. Dialogue for sure has the salutary effect of demolishing barriers between religions and discovering their inter-relatedness. Inter-religious dialogue has brought people of different religions together around common concerns. It has also generated openness and good will among people of different faiths. But how many conversions could be attributed to dialogue.

And what has been the result of inculturation in the social field? From the beginning the Church was solidly present in social activities. Mother Teresa was an eloquent witness of Christian social service and concern for the poor. But how many converts has she won? Today the Church has gone a step further and is very much present in the defense and liberation struggles of the poor. ${ }^{4}$ The action groups have brought together people of different faiths. In many of these groups there exist deep sharing and communion and the spirit of self giving. ${ }^{5}$ But how many conversions have been recorded as a result of the witness and service of the action groups?

\subsection{Holiness of life}

\footnotetext{
${ }^{3}$ Paul Pattathu, Ashram Spirituality: A Search into the Christian Ashram Movement against its Hindu Background (Indore: Satprakashan, 1997), 5-6.

${ }^{4}$ Report of the CBCI Commission \& National Centres \& Regional Bishops' Councils 1992-1993 (New Delhi: CBCI Centre),188

${ }^{5}$ For a Study of the Actions Groups see, Felix Wilfred, "Harbingers of Hope: Action Groups in India Today" in The Emergent Church in a New India (Thiruchirappalli: 1988), 97-127; See also six different articles on People's Movements in Jeevadhara 88 (July 1985). 
India, given its instinctive religious bent of mind has always revered men and women of sanctity. Even today people are drawn to holy people and holy places. That is why the sages and saints of India were and are able to wield exceptional influence over vast sections of the people. It is generally felt that Indian Christianity, unlike Hinduism, did not produce many people of exceptional holiness. The Indian church is noted more for its social and charitable involvement rather than for strictly religious service. And therefore the Church failed in attracting the masses into its fold.

This argument too can be refuted by referring to the experience of Buddhism and other factors. Buddha and the disciples of Buddha were men of outstanding holiness. Buddhist spirituality of asceticism, compassion for all forms of life and non-violence are all elements of holiness. With all that, as pointed out earlier, Buddhist influence on the Indian society has been marginal.

Besides, the claim that Christianity in India did not produce saints too needs to be critically looked at. Was not Francis Xavier filled with the spirit of God and driven by him in his missionary undertakings? We may also point to modern saints like Sr. Alphonsa, Fr. Chavara Kuriakose and Mother Teresa. Mother Teresa is a popular saint of the time venerated all over the world. But how many non-Christians have embraced Christianity as a result of her witness and holiness?

\section{Factors that contributed to the limited success}

What then are the factors that led to a good number of conversions to Christianity in recent times? The principal reason for conversion according to Hindu sociologists is socio-economic upward mobility of the convert. They point out that the vast majority of converts to Christianity hail from the poor sections of society and are driven by the desire for a better share in the fortunes of the nation. Their conclusions are corroborated also by the researches of many Christian sociologists. A study conducted by Julian Saldhana came to the conclusion that the conversion movements among different groups are motivated by different factors. Those among the dalits are motivated by a combination of religious and social factors. Changes of tribal groups were mainly the result of socio-psychological factors, that is, part of the search for a new identity in a radically changed social order which left them disoriented and demoralised. State pressure is recognized as a major factor in the conversions of the $16^{\text {th }}$ and $17^{\text {th }}$ centuries in Goa. And the relatively few conversions of Brahmins are the result of religio-spiritual considerations. Thus several factors are involved in the conversion movements. Prominent among them are socio-cultural and historical factors. But the personal, social and religious motivations must also be considered along with religio-social context. ${ }^{6}$

Also to be remembered is the fact that the renewal movements, especially the catholic charismatic movement which attract so many people from other religions too do not generally succeed in winning converts. Many of them come in search of favours; others come precisely because they have received special graces and blessings from their presence in such centres. But even in the case of these people there is no great desire to become Christians, but they feel quite content to continue to frequent Christian prayer services and still remain in their own religion.

We must also remember that in spite of the Church's alienation from the life and culture of the people many of the leaders of the national movement were positively disposed towards the Christian message. Some of them like Keshub Chunder Sen and Pratap Chandra Mozoomdar had deep personal experience of Christ and even became missionaries and prophets of the Christian faith. However all of them, without exception refused to accept baptism and church membership.

\section{What is the Spirit saying to the Indian Christians?}

All these point to one thing: The Indian religious psychology, is very much unlike that of Europeans. Even though the people are willing and open to accept the message of Jesus, and indeed of all religions, the idea of change of religion is repugnant to their innate religious sensibilities. Even those who are positively disposed towards Christians and Christian mission do not generally approve the change of religion. Could these historical data be the way the Spirit of Jesus is leading the Indian Christians? Is he perhaps asking the Indian Christians to change direction? Is there an alternative way in which Christian mission can be more effectively and fruitfully carried out? What could be the alternative? It is my conviction that in the context of the failure of mission understood in the traditional sense of that word, and contemporary experience, the approach opened up by Mother Teresa holds great promises for the future of Christians in India.

\section{Mother Teresa the missionary}

There is no hiding of the fact that Mother Teresa was one of the greatest missionaries of all times. Already as a young girl she wanted to be a missionary. In fact this was her self-designation. In a letter sent to her home on her arrival in India she wrote: "Pray much for us that we may be good and courageous

${ }^{6}$ Julian Saldanha, "Patterns of Conversion in Indian Mission History", 79-95. 
missionaries." ${ }^{, 7}$ In a letter to her former confessor back at home she wrote: "...to make you pray a little more for your missionary." 8 The different Congregations that she founded are all known as Missionaries of Charity. She is known all over the world as a missionary. But she was a missionary with a difference. Her style was different from the one generally sanctioned by tradition and recent mission documents of the Church. ${ }^{9}$ But where is her mission theology to be found? How are we to trace it?

Unfortunately Mother Teresa did not leave any great literary legacy behind. She did not write any theological treatises. In fact she consciously avoided writing since she wanted to shun all forms of publicity. The only literary output to her credit, are some letters that she wrote to different people. ${ }^{10}$ Their contents are of a practical nature and not theological or doctrinal. Even these she tried to retrieve so as to destroy them in order to remain hidden. If she was not a writer, she was not a speaker either; whenever called upon to speak, even at the most august gatherings, as for example at the Nobel Ceremony, she spoke about little things like the need for caring, sharing and loving ${ }^{11}$. This was the same message she gave to all: Christians and non-Christians alike. Since neither her speeches nor her writings give us any insight into her understanding of mission one must look at her praxis. The mission theology of Mother Teresa is to be gathered almost exclusively from her missionary praxis, that is, from what she did, and what she did not do. Behind her praxis there lies a very articulate mission theology.

\section{Her Missionary praxis - What she did}

In what did her praxis consist? There is only one simple truth that she wanted to communicate through her word and deed: God is our loving Father and therefore, we, his children must love one another in all the concreteness of that word. Her mission consisted in intensely loving and caring for the poorest of the poor. She had a special predilection for the least and the lost. For her, love goes beyond mere feelings or sentiments or even prayers; it is real and concrete. It consists in providing the victims of poverty and deprivation the immediate necessities of life - food, shelter and clothing. Willingness to endure all hardships, passion, tenderness and real affection for the sick and the poor are the ingredients of this love. That explains her stoic courage in the face of unfounded criticisms, insults and humiliation. That also explains the kisses that she used to lavishly shower upon the dilapidating bodies of the lepers and their stinking wounds. It was the tender and affectionate love of the Father made real in terms of satisfying their immediate needs. The care and love for the poor took the form of all sorts of social and charitable services which brought immediate relief for the poor. Her mission consisted almost exclusively of these activities.

\subsection{The Absence of Traditional Methods - What she did not Do ?}

The traditional style of missionary work was conspicuously absent in Mother Teresa. In her missionary praxis there was no preaching, no proclamation, no baptism, no catechesis, no distribution of Christian literature, no attempt at numerical increase; she did not undertake any missionary journey after the example of St. Paul, or in modern times, St. Francis Xavier, who went about like a whirlwind preaching and baptizing. She never went about openly preaching about Jesus or Christianity or salvation; she did not undertake organized forms of inter-religious dialogue, nor did she worry about inculturation.

Nevertheless the right wing Hindus accused her of being a missionary, bent on converting Indians to Christianity and therefore, an agent of the imperialist west. The right wing Hindu organization, has dubbed the award of Nobel Prize for Mother Teresa as anti-Indian. In its editorial titled "Nothing Noble about Nobel" the Organizer wrote: "For when all is said and done she is a missionary. In serving the poor and the sick her sole objective is to influence people in favour of Christianity, and if possible to convert them...Missionaries are instruments of Western imperialist countries - and not - innocent voices from God." ${ }^{12}$

But her close associates are unanimous in their testimony that she did not indulge in converting people to Christianity. Mr. Navin Chawla, her confidant and biographer, recently wrote: "She was criticized for encouraging conversion to her faith. Yet, in all the 23 years I knew her, she never once whispered such a suggestion. However I did ask her if she did convert people to her religion. Without a moment's hesitation, she

\footnotetext{
${ }^{7}$ Brian Kolodiejchuk, ed., Mother Teresa Come Be My Light (London: Rider, 2007), 17.

${ }^{8}$ Kolodiejchuk, ed., Mother Teresa Come, 20.

${ }^{9}$ See Ad gentes, Evangelii nuntiandi, Redemptoris missio etc.

${ }^{10}$ These have been recently edited and published by Brian Kolodiejchuk, ed., Mother Teresa Come Be My Light (London: Rider, 2007)

${ }^{11}$ See the Nobel Speech in Brian Kolodiejchuk, ed., Mother Teresa Come Be My Light (London: Rider, 2007), 291-92; See also Navin Chawla , "A Pencil in the Hands of the Lord" in The Week, 29 August 2010, 26; Eileen Egan, Such a Vision of the Street: Mother Teresa - The Sprit and the Work (London: Sidgwick \&Jackson, 1986), 390-393.

${ }^{12}$ Quoted in S.M. Michael, "Analysis of the Society at the Micro Level - The Indian Rural Reality", in D. S. Amalorpavadass, The Indian Church in the Struggle for a New Society (Bangalore: 1981), 137.
} 
said "I do convert. I convert you to be a better Hindu, a better Muslim, a better Protestant, a better Sikh. Once you have found God, it is up to you to do with him as you wish."13

Mother Teresa for sure knows too well that the acceptance of Christianity by a handful of her nationally and internationally renowned followers (in fact she had many of them in her fold) would have drawn thousands of people to Christianity. But still she did not even indirectly propose to anyone to get converted to Christianity. It may be even more accurate to affirm that she consciously resisted this temptation, realizing that it would limit her universal appeal and reach. She gave up the narrow understanding of mission in favour of a more universal and all embracing approach. If she were to indulge in traditional styles it would certainly have limited her appeal and popularity and many would have shrunk back. This fact is also significant when we evaluate the missionary work of Mother Teresa.

\section{The Source of her Strength}

In spite of her not proclaiming and preaching about Jesus, not even for a moment, did she hide the fact that the source of her strength and inspiration was, Jesus. She was not a mere social worker; her convictions crystallized in the course of the contemplation of the countenance of Jesus in the poor. She could see Jesus in the suffering and dying. With childlike trust and innocence she held on to him. For this reason neither insult, nor criticism, nor rejection nor anything else could deter her from doing her work with single-minded dedication. As far as she was concerned, in the poor and dying she was serving Jesus himself. She was utterly dependent on Him. It was in fact His power and His love for the poor that was made manifest through her. She always considered her as nothing and tried to relegate herself to the background. When asked about the source of her strength, with childlike simplicity she would say that she found Jesus in every suffering and poor person. In the lepers, the slum dwellers, and the poorest of the poor, regardless of which religion they belonged to, she was able to behold the face of Jesus. "Truly I say to you, just as you did it to one of the least of these who are members of my family you did it to me" (Mt 25:40). This conviction gave her the inner resources to accept all hardships.

\section{The fruit of her Mission}

The greatest achievement of Mother Teresa, to my mind, is not the fact that she was able to bring solace and comfort to thousands of people all over the world; rather the deep influence that she exerted over the international community. No individual in recent history has touched the hearts of people so profoundly across the world, as mother did; no one has effected such a massive conversion of hearts of people. Millions across the world venerated her. The world rated her as the greatest and noblest human being who lived on the earth. Her devotees acclaim her as 'divinity in human form', 'human understanding personified. ${ }^{14}$ She broke down all forms of barriers and forged a wonderful unity of mankind at the international level in favour of the poor. She knit together believers and unbelievers, young and old, rich and poor, black and white. The presence of a host of world leaders at her funeral, and the many awards that she received ${ }^{15}$ are all indications of the world's admiration and recognition of her works.

She continues to live on in the hearts, memory, imagination and affections of the people. At her memory the arrogant and humble alike go down on their knees, tears roll down from haughty eyes; passions are calmed, hearts are lifted to greater heights, and noble thoughts and resolves fill the minds of those who visit her Samadhi or her homes. Contributions continue to come from the least expected quarters.

Though fiercely catholic, she grew beyond Catholicism; she was inter-religious; she was a universal citizen. During the Nobel ceremonies in Oslo, a probing journalist, after pointing out that she was born in Yugoslavia and lived in India while her work extended to all over the world asked: "And you, mother Teresa, how do you feel about yourself?" Her prompt reply was: "By blood and origin I am an Albanian. My citizenship is Indian. I am a Catholic nun. As to my calling, I belong to the whole world. As to my heart, I belong entirely to the heart of Jesus." 16 She recruited collaborators from all religions and political affiliations. She blunted the aggression of the arrogant and selfish by the power of her love. She awakened mankind to their social responsibilities. She promoted love; revived and renewed the hearts of people, enkindled hope among the sick and the poor. She effected a change in the world's attitude towards the poor. Mother Teresa was humanity at its best and religion in its purest!

\footnotetext{
${ }^{13}$ Navin Chawla, "A Pencil in the Hands of the Lord" in The Week, 29 August 2010, 28. See also the testimony of her close associate and photographer and biographer Raghu Rai, in The Week, 29 August 2010, 23; Kushwant Singh, "The Tough Core" in The Week, 28 August 2010, 32 .

${ }^{14}$ See V. P. Singh, "Divinity in Human Form" in Babu Joseph, ed., Tracing the Footsteps of Mother Teresa (Department of Public Relations, CBCI \& Varanasi Diocese: New Delhi, 2003): 25-26.

${ }^{15}$ She has received a total of 124 national and international awards. See Babu Joseph, ed., Tracing the Footsteps of Mother Teresa, p.111.

${ }^{16}$ Quoted in Eileen Egan, Such a Vision of the Street: Mother Teresa - The Sprit and the Work (London: Sidgwick \& Jackson, 1986), 399.
} 
Her work is still continued not just by the three congregations she founded, but by many good willed souls - not all Catholics - all over the world. There are many people, who, silently, under the inspiration of Mother, are engaged in humble service of the poor. Such was the impact of the person and her work.

\section{Implications for Mission in India}

Here is a mission theology that is new. There is no preaching, no baptism. If someone wants to accept baptism and join the church he or she is welcome, but the focus is not on baptism or church membership. Several ingredients of the mission theology of the official Church documents are conspicuously absent in her approach. Yet, her approach was most effective in terms of conversion of hearts. If conversion of hearts is the goal of mission, then Mother Teresa was undoubtedly the greatest missionary of all times. Hers was a higher state of consciousness of mission. At that stage, the ordinary issues that generally occupy much of the energies of the missionaries and the hierarchy, like rites and doctrines and the orthodoxy of practices, were no issues at all for her; at that level mission has much more serious issues to tackle. Religion understood in terms of love and service has many takers all over the world even today; it has got a wide market. Could this give a hint to the future of mission in India?

The Asian Synod, while still labouring under the traditional understanding of mission, seems to offer some new orientations. The sub title of the post-synodal document Ecclesia in Asia is indicative of this trend: "his mission of love and service in Asia..." Here mission is conceived in terms of love and service. Such a mission will evoke positive response among the people; conversion of hearts will take place, religions will be brought together; communal conflicts and mutual distrust will disappear; there will be inter-religious collaboration and it will contribute to the emergence of a new humanity, and thus the gospel will reach the ends of the earth. 